\title{
Fatty acid profile of pebbly fish, Alestes baremoze (Joannis, 1835) from Lake Albert, Uganda: Implications for its feed requirements
}

\author{
Nasser Kasozi ${ }^{1}$, Gerald Iwe Degu ${ }^{1}$, John Walakira ${ }^{1}$, Victoria Tibenda Namulawa ${ }^{2}$ \\ ${ }^{1}$ Abi Zonal Agricultural Research and Development Institute, National Agricultural Research \\ Organization. ${ }^{2}$ Aquaculture Research and Development Center, National Agricultural Research \\ Organization \\ *Corresponding author. @ nasser.kasozi@naro.go.ug
}

\begin{abstract}
The objective of this study was to establish the fatty acid profile of Alestes baremoze, with a view of establishing its dietary fatty acid requirements. Fish samples from Lake Albert were categorized into four classes according to fork lengths $(1-10 \mathrm{~cm}, 11-20 \mathrm{~cm}, 21-30 \mathrm{~cm}$, and $31-40$ $\mathrm{cm}$ ), with each class comprising of six fish. In addition, eggs were collected from six sexually mature females. A total of 35 fatty acids were identified and categorized into saturated fatty acids (SFAs), monounsaturated acids (MUFAs), and polyunsaturated fatty acids (PUFAs). SFAs accounted for $5.07 \%$ to $37.05 \%$, MUFAs and PUFAs constituted $20.65 \%$ to $53.78 \%$, and $10.34 \%$ to $66.10 \%$ respectively, of total fatty acids in all studied fish size classes. The results from this study indicated that fatty acid composition in A. baremoze varied significantly with size classes. The findings may provide guidance on the fatty acid inclusions for diets formulated for this fish under culture conditions.
\end{abstract}

Keywords: Alestes baremoze, fatty acid composition, fatty acid profiles, Lake Albert.

\section{Introduction}

Pebbly fish, Alestes baremoze is a freshwater potamodromous and benthopelagic species found mainly in shore of lakes across Africa (Kasozi et al., 2017; Diouf et al., 2020). The fish belongs to order Characiformes and family Alestidae. A. baremoze is one of the most economically important species facing overexploitation in Lake Albert (Kasozi et al., 2017). As a result, the catches have significantly reduced and there are efforts to develop its culture technologies to increase its production under aquaculture (Kasozi et al., 2017). However, studies undertaken on domestication of new aquaculture species reveal that such ventures can never be successful without an appropriate feeding strategy (Yanes-Roca et al., 2009; Namulawa et al., 2011). It is therefore important that feeding protocols are in place to guide artificial feed formulation for this species once in culture. Although Kasozi et al. (2019) reported the dietary amino acid requirements for $A$. baremoze, the culture of this fish is still hampered by limited information regarding its fatty acid profile. 
Estimates of dietary requirements in fish have utilized different methods such as: gut content analysis (Gümüş et al., 2002), fixed isotope analysis (Post, 2002; Campbell et al., 2005) and the dose response method (Shearer, 2000; Hamre et al., 2013) among others. Such methods are however characterized by different inadequacies. For example, in the gut content analysis method, the contents of most guts cannot be separated into prey categories for quantification because of the presence of unidentifiable and inseparable partially digested material (Baker et al., 2014). Similarly, the fixed isotope method uses mixing models which rely on estimates in isotopic changes between the consumer and prey to generate the isotope discrimination factor (Britton and Busst, 2018). This factor is affected by age, body size, diet composition, and tissue analyzed (Britton and Busst, 2018). The dose response method does not take into consideration the ability of the fish to digest the presented diet and the contribution of the dietary energy in causing fish growth, thereby presenting uncertain results (NRC, 1993).

Recent research has engaged more robust approaches that rely on the nutritional profiles of fish to investigate dietary requirements. For example, understanding the fatty acid profile of the fish of interest, closely explains its nutritional requirements (Robin et al., 2003). This is because of the diversity of fatty acids and their patterns in fish, coupled with the narrow limitations on their biosynthesis. Fatty acids are transferred conservatively from the food source and incorporated into the neutral lipids of the consumer virtually unaltered, there by conserving the fatty acid signatures from the diets to consumer (Glencross, 2009).

Fatty acids are an important dietary component in all vertebrates, mainly useful as energy sources (Glencross, 2009). They are known to richly occur in fish as either saturated or unsaturated, and of major interest are the polyunsaturated fatty acids (Sargent et al., 2002; Namulawa et al., 2011). These are specifically important because they promote normal body growth and development, reproduction, membrane structure maintenance, visual development, stress resistance and general body immunity in fish (Sargent et al., 2002; Glencross, 2009). Fatty acids are one of the most essential dietary requirements in fish and research suggests that these can be revealed by their fatty acid profile of the fish in question (Robin et al., 2003). The fatty acid profile for $A$. baremoze is not known yet, which makes it impossible to know its fatty acid dietary requirements. We investigated the fatty acid profile of $A$. baremoze of Lake Albert with a major objective of establishing its dietary fatty acid requirements that will guide feed formulation procedures for $A$. baremoze once it is domesticated.

\section{Materials and Methods}

\section{Sample collection and preparation}

A total of 30 fish of various sizes were collected from Abok fish landing site $\left(02^{\circ} 14.46^{\circ} \mathrm{N}\right.$ $31^{\circ} 19.15^{\circ} \mathrm{E}$ ) along Lake Albert, Pakwach district (Figure 1). The samples were divided into four size classes according to their fork lengths (1-10, 11-20, 21-30 and 31-40 cm) with each class comprising six fish. According to Diouf et al. (2020), adult A. baremoze range between 30 and $45 \mathrm{~cm}$ long. Therefore, basing on those findings, in addition with the observed mean lengths of the fish at the landing site, the grouping of the final size class was chosen. In addition, the eggs were collected from six sexually mature females (43.5 to $45.5 \mathrm{~cm}$ fork length). All samples were immediately placed on ice, kept cold $\left(4^{\circ} \mathrm{C}\right)$ and transported in polystyrene boxes to maintain freshness. Upon arrival at Chemiphar Research Laboratories, Uganda Ltd., whole fish, excluding the viscera, liver, and gonads were individually chopped, minced on ice and frozen for further processing. The eggs and whole body were separately homogenized and stored at 
$-20^{\circ} \mathrm{C}$ before analysis. Appropriate precautions were taken to minimize oxidation throughout the analysis by conducting processing steps at $4^{\circ} \mathrm{C}$. In each case, the analyses were carried out in duplicate.

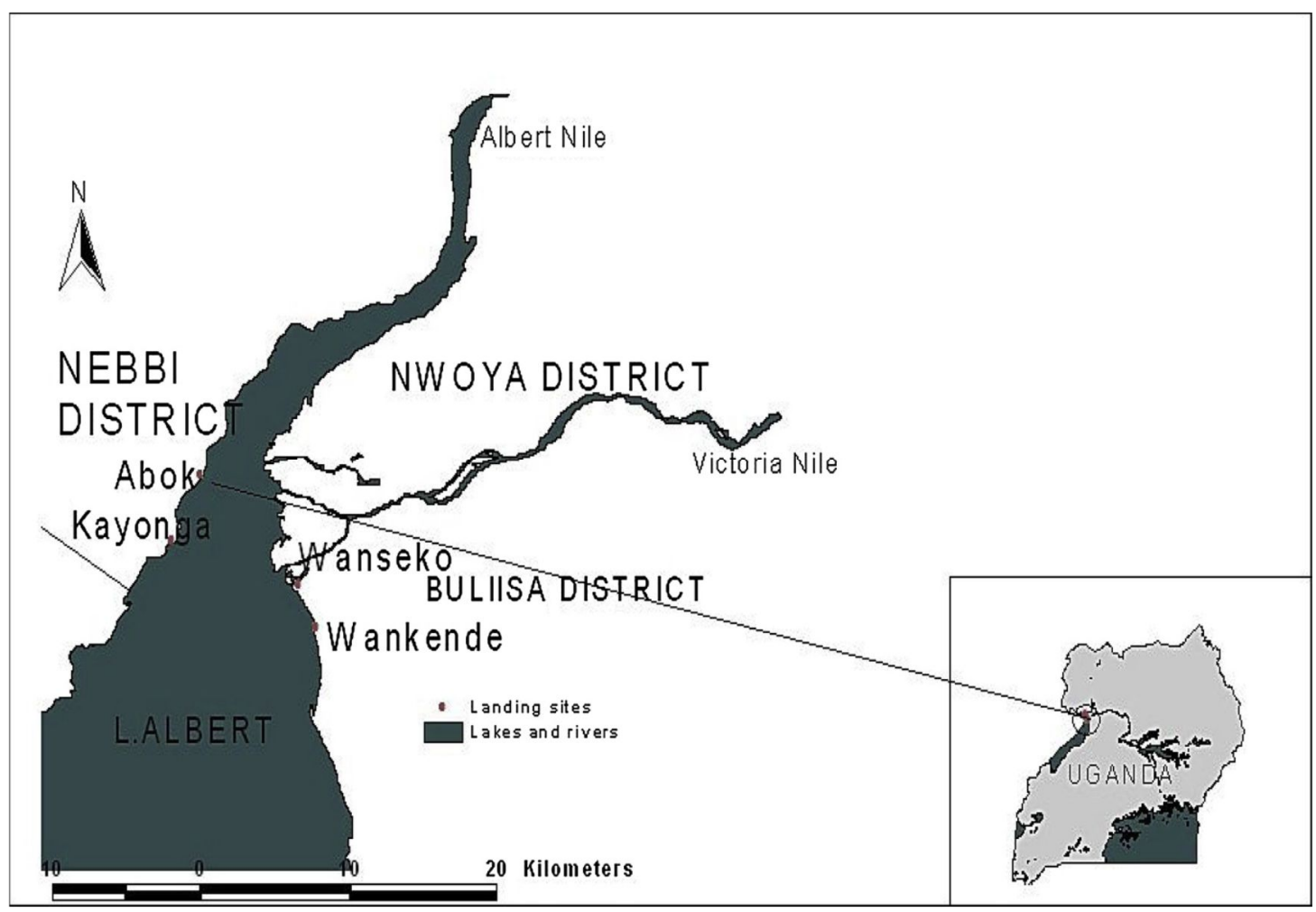

Figure 1. Location of Abok fish landing site on Lake Albert, Uganda.

\section{Total lipid extraction}

Lipid extraction was performed according to methods described by Bligh and Dyer (1959), with slight modifications as in Kinsella et al. (1977). Approximately $100 \mathrm{~g}$ of completely homogenized fish samples from each size category were added into a mixture of methanol (100 $\mathrm{mL}$ ) and chloroform $(50 \mathrm{~mL})$ and left to stand for $1 \mathrm{hr}$. A total of $50 \mathrm{~mL}$ distilled water was added to the mixture, which was blended for 30 seconds. The homogenate was stirred with a glass rod and filtered through Whatman No. 1 filter paper $(8 \mu \mathrm{m})$ on a Buchner funnel with vacuum suction. About $30 \mathrm{~mL}$ of chloroform was used to rinse the remainder. The filtrate was left to settle in order to separate into the organic and aqueous layers. The lower clear phase was drained into a $100 \mathrm{~mL}$ round-bottom flask and concentrated with a rotary evaporator (Rotavapor ${ }^{\circledR} \mathrm{R}-215$, Switzerland) at $60^{\circ} \mathrm{C}$.

\section{Preparation of fatty acids methyl esters (FAMEs) and analysis of fatty acids}

FAME preparation followed procedures in Morrison and Smith (1964) and Kinsella et al. (1977). The fatty acids in the total lipid were esterified into methyl esters by saponification with $0.5 \mathrm{~N}$ methanolic $\mathrm{NaOH}$ and transesterified with $14 \% \mathrm{BF}_{3}(\mathrm{v} / \mathrm{v})$ in methanol. The 
determination of types and levels of omega 3 PUFAs was done by using a gas chromatograph mass spectrometer (GC-MS-QP2010 Ultra), which was equipped with flame ionization detector (FID). Helium was used as the carrier gas at a flow rate of $2 \mathrm{~mL} / \mathrm{min}$. The injector temperature was at $260^{\circ} \mathrm{C}$. The temperature of the column was kept at $50^{\circ} \mathrm{C}$ for $5 \mathrm{~min}$ after injection and thereafter increased to $180^{\circ} \mathrm{C}$ at a rate of $20^{\circ} \mathrm{C} / \mathrm{min}$, followed by an increase of $2^{\circ} \mathrm{C} / \mathrm{min}$ to $200^{\circ} \mathrm{C}$, held for $11 \mathrm{~min}$ and then finally ramped to $250^{\circ} \mathrm{C}$ at $2^{\circ} \mathrm{C} / \mathrm{min}$, hold for $2.5 \mathrm{~min}$. Fatty acids were quantified by comparing their peaks with the relevant peak areas of the corresponding standard fatty acids where each fatty acid was then expressed as a percentage of the total fatty acids quantified.

\section{Statistical analysis}

Fatty acids were categorized into SFAs, MUFAs, and PUFAs for each size class to show their composition. Differences in fatty acid content among the analyzed fish of different size classes and eggs were determined by one-way analysis of variance (ANOVA) using SAS statistical software (SAS, 2004). Multiple comparisons of means were done using the Duncan method with $P$-value $\leq 0.05$ considered statistically significant.

\section{Results}

\section{Fatty acid profiles}

Thirty-five (35) different fatty acids in the eggs and whole body of $A$. baremoze were identified (Table 1). Wide variations in the fatty acid composition were shown among the fish size groups. SFAs accounted for $5.65 \%$ to $37.05 \%$ of total fatty acids in all studied fish categories; MUFAs constituted $20.65 \%$ to $53.78 \%$; and PUFAs accounted for $10.34 \%$ to $66.10 \%$. 
Table 1. Comparison of fatty acid composition (expressed as percentage of total fatty acids) of the different size classes of whole-body and eggs of Alestes baremoze.

\begin{tabular}{|c|c|c|c|c|c|c|}
\hline Common name & Fatty acids & 1 to $10 \mathrm{~cm}$ & 11 to $20 \mathrm{~cm}$ & 21 to $30 \mathrm{~cm}$ & 31 to $40 \mathrm{~cm}$ & Eggs \\
\hline Butyric acid & $\mathrm{C} 4: 0$ & $0.05 \pm 0.07^{\mathrm{b}}$ & $0.10 \pm 0.0^{\mathrm{b}}$ & $0.08 \pm 0.0^{\mathrm{b}}$ & $0.04 \pm 0.015^{b}$ & $0.20 \pm 0.0^{\mathrm{a}}$ \\
\hline Caproic acid & C 6:0 & $0.10 \pm 0.0^{\mathrm{a}}$ & $0.10 \pm 0.0^{\mathrm{a}}$ & $0.11 \pm 0.0^{\mathrm{a}}$ & $0.09 \pm 0.047^{\mathrm{a}}$ & $0.12 \pm 0.0^{\mathrm{a}}$ \\
\hline Caprylic acid & C 8:0 & $0.10 \pm 0.0^{\mathrm{b}}$ & $0.05 \pm 0.07^{\mathrm{b}}$ & $0.55 \pm 0.0^{\mathrm{a}}$ & $0.06 \pm 0.06^{\mathrm{b}}$ & $0.14 \pm 0.01^{\mathrm{b}}$ \\
\hline Capric acid & C 10:0 & $0.25 \pm 0.21^{\mathrm{a}}$ & $0.00 \pm 0.0^{\mathrm{a}}$ & $0.08 \pm 0.0^{\mathrm{a}}$ & $0.23 \pm 0.27^{\mathrm{a}}$ & $0.09 \pm 0.0^{\mathrm{a}}$ \\
\hline Undecanoic acid & C 11:0 & $0.10 \pm 0.0^{\mathrm{b}}$ & $0.05 \pm 0.07^{\mathrm{b}}$ & $0.43 \pm 0.6^{\mathrm{a}}$ & $0.19 \pm 0.20^{\mathrm{ab}}$ & $0.00 \pm 0.0^{\mathrm{b}}$ \\
\hline Lauric acid & C 12:0 & $0.10 \pm 0.0^{\mathrm{ab}}$ & $0.05 \pm 0.07^{\mathrm{ab}}$ & $0.15 \pm 0.0^{\mathrm{a}}$ & $0.08 \pm 0.07^{\mathrm{ab}}$ & $0.00 \pm 0.0^{\mathrm{b}}$ \\
\hline Tridecanoic acid & C 13:0 & $0.05 \pm 0.07^{\mathrm{b}}$ & $0.00 \pm 0.0^{\mathrm{b}}$ & $9.31 \pm 0.0^{\mathrm{a}}$ & $0.06 \pm 0.047^{\mathrm{b}}$ & $0.00 \pm 0.0^{\mathrm{b}}$ \\
\hline Myristic acid & C 14:0 & $0.05 \pm 0.07^{\mathrm{b}}$ & $0.00 \pm 0.0^{\mathrm{b}}$ & $0.09 \pm 0.0^{\mathrm{b}}$ & $4.78 \pm 1.70^{\mathrm{a}}$ & $0.00 \pm 0.0^{\mathrm{b}}$ \\
\hline Pentadecanoic acid & C 15:0 & $0.50 \pm 0.56^{\mathrm{a}}$ & $0.05 \pm 0.07^{\mathrm{a}}$ & $0.46 \pm 0.0^{\mathrm{a}}$ & $0.19 \pm 0.17^{\mathrm{a}}$ & $0.00 \pm 0.0^{\mathrm{a}}$ \\
\hline Palmatic acid & C 16:0 & $0.85 \pm 0.49^{a}$ & $0.55 \pm 0.07^{\mathrm{a}}$ & $0.77 \pm 0.0^{\mathrm{a}}$ & $0.28 \pm 0.06^{\mathrm{ab}}$ & $0.00 \pm 0.0^{\mathrm{b}}$ \\
\hline Heptadecanoic acid & C 17:0 & $0.05 \pm 0.07^{\mathrm{c}}$ & $0.00 \pm 0.0^{\mathrm{c}}$ & $13.88 \pm 0.0^{\mathrm{b}}$ & $21.31 \pm 0.04^{\mathrm{a}}$ & $0.00 \pm 0.0^{\mathrm{c}}$ \\
\hline Stearic acid & C 18:0 & $0.00 \pm 0.0^{\mathrm{c}}$ & $0.00 \pm 0.0^{\mathrm{c}}$ & $3.62 \pm 0.0^{\mathrm{b}}$ & $6.64 \pm 1.28^{\mathrm{a}}$ & $0.00 \pm 0.0^{\mathrm{c}}$ \\
\hline Arachidic acid & C 20:0 & $0.00 \pm 0.0^{\mathrm{c}}$ & $0.05 \pm 0.07^{\mathrm{c}}$ & $0.38 \pm 0.0^{\mathrm{b}}$ & $0.20 \pm 0.28^{\mathrm{bc}}$ & $1.29 \pm 0.0^{\mathrm{a}}$ \\
\hline Heneicosanoic acid & C 21:0 & $0.30 \pm 0.42^{\mathrm{a}}$ & $0.00 \pm 0.0^{\mathrm{a}}$ & $0.00 \pm 0.0^{\mathrm{a}}$ & $0.00 \pm 0.0^{\mathrm{a}}$ & $0.41 \pm 0.0^{\mathrm{a}}$ \\
\hline Behenic acid & C 22:0 & $0.00 \pm 0.0^{\mathrm{a}}$ & $0.00 \pm 0.0^{\mathrm{a}}$ & $0.00 \pm 0.0^{\mathrm{a}}$ & $0.00 \pm 0.0^{\mathrm{a}}$ & $0.00 \pm 0.0^{\mathrm{a}}$ \\
\hline Tricosanoic acid & C 23:0 & $2.85 \pm 1.06^{\mathrm{bc}}$ & $8.05 \pm 0.77^{\mathrm{a}}$ & $3.73 \pm 0.9^{b}$ & $2.80 \pm 0.35^{\mathrm{bc}}$ & $1.62 \pm 0.61^{\mathrm{c}}$ \\
\hline Lignoceric acid & C 24:0 & $0.30 \pm 0.42^{b}$ & $0.00 \pm 0.0^{\mathrm{b}}$ & $0.00 \pm 0.0^{\mathrm{b}}$ & $0.11 \pm 0.15^{b}$ & $1.19 \pm 0.0^{\mathrm{a}}$ \\
\hline$\Sigma$ SFAs & & $5.65 \pm 0.68^{d}$ & $9.05 \pm 1.94^{\mathrm{c}}$ & $33.65 \pm 0.88^{b}$ & $37.05 \pm 5.29^{\mathrm{a}}$ & $5.07 \pm 0.52^{\mathrm{d}}$ \\
\hline Myristoleic acid & C $14: 1 \omega 5$ & $4.05 \pm 2.61^{\mathrm{a}}$ & $2.15 \pm 0.49^{\mathrm{ab}}$ & $0.168 \pm 0.0^{\mathrm{b}}$ & $0.011 \pm 0.01^{b}$ & $3.65 \pm 0.3^{\mathrm{a}}$ \\
\hline cis-10-pentadecenoic acid & C $15: 1 \omega 5$ & $0.10 \pm 0.0^{\mathrm{b}}$ & $0.20 \pm 0.14^{\mathrm{ab}}$ & $0.09 \pm 0.0^{\mathrm{b}}$ & $0.11 \pm 0.08^{b}$ & $0.38 \pm 0.1^{\mathrm{a}}$ \\
\hline Palmitoleic acid & C $16: 1 \omega 7$ & $0.55 \pm 0.35^{\mathrm{a}}$ & $0.05 \pm 0.07^{\mathrm{b}}$ & $0.09 \pm 0.0^{\mathrm{b}}$ & $0.03 \pm 0.005^{\mathrm{b}}$ & $0.00 \pm 0.6^{\mathrm{b}}$ \\
\hline cis-10-heptadecenoic acid & C $17: 1 \omega 8$ & $14.70 \pm 2.96^{\mathrm{a}}$ & $15.80 \pm 3.11^{\mathrm{a}}$ & $17.08 \pm 0.1^{\mathrm{a}}$ & $0.08 \pm 0.09^{b}$ & $16.66 \pm 0.0^{\mathrm{a}}$ \\
\hline Oleic acid & C $18: 1 \omega 9$ & $0.05 \pm 0.07^{\mathrm{c}}$ & $0.10 \pm 0.14^{\mathrm{c}}$ & $6.92 \pm 0.07^{\mathrm{a}}$ & $0.052 \pm 0.05^{\mathrm{c}}$ & $4.44 \pm 0.0^{\mathrm{b}}$ \\
\hline Eicosenoic acid & C 20:1 $\omega 9$ & $1.15 \pm 0.49^{\mathrm{a}}$ & $0.45 \pm 0.35^{\mathrm{a}}$ & $0.64 \pm 0.0^{\mathrm{a}}$ & $0.61 \pm 0.06^{\mathrm{a}}$ & $1.01 \pm 0.0^{\mathrm{a}}$ \\
\hline Erucic & C 22:1 $\omega 9$ & $8.70 \pm 1.27^{\mathrm{c}}$ & $1.90 \pm 0.14^{\mathrm{d}}$ & $28.52 \pm 0.0^{\mathrm{b}}$ & $46.13 \pm 3.06^{\mathrm{a}}$ & $0.00 \pm 0.0^{\mathrm{d}}$ \\
\hline Nervonic acid & C 24:1 $\omega 9$ & $0.55 \pm 0.77^{b}$ & $0.00 \pm 0.0^{\mathrm{b}}$ & $0.28 \pm 0.0^{\mathrm{b}}$ & $0.35 \pm 0.49^{b}$ & $4.00 \pm 0.0^{\mathrm{a}}$ \\
\hline
\end{tabular}




\section{$\Sigma$ MUFAs}

$\alpha$-linolenic acid (ALA)

Eicosatrienoic acid (ETE)

Eicosapentaenoic acid (EPA)

Docosahexaenoic acid (DHA)

Linoleic acid (LA)

$\gamma$-linolenic acid (GLA)

Eicosadienoic acid

Dihomo- $\gamma$-linolenic acid

Arachidonic acid (ARA)

Docosadienoic acid

$\Sigma$ PUFAs

\section{$\Sigma \omega 3$}

$\Sigma \omega 6$

$\Sigma \omega 3 / \omega 6$
C $18: 3 \omega 3$

C $20: 3 \omega 3$

C $20: 5 \omega 3$

C 22:6 $\omega 3$

C $18: 2 \omega 6$

C $18: 3 \omega 6$

C $20: 2 \omega 6$

C $20: 3 \omega 6$

C $20: 4 \omega 6$

C 22:2 $\omega 6$
$0.05 \pm 0.07^{\mathrm{a}}$

$0.80 \pm 0.70^{\mathrm{a}}$

$51.85 \pm 1.06^{\mathrm{a}}$

$0.30 \pm 0.42^{\mathrm{c}}$

$1.85 \pm 0.21^{\mathrm{b}}$

$0.05 \pm 0.07^{\mathrm{c}}$

$0.25 \pm 0.07^{\mathrm{b}}$

$0.80 \pm 0.70^{\mathrm{a}}$

$0.20 \pm 0.28^{\mathrm{d}}$

$1.50 \pm 1.56^{\mathrm{cd}}$

$57.15 \pm 4.87^{\mathrm{c}}$

\section{0}

4.85

10.92
$20.65 \pm 4.38^{d}$

$0.55 \pm 0.21^{\mathrm{a}}$

$0.00 \pm 0.0^{\mathrm{a}}$

$0.45 \pm 0.50^{\mathrm{b}}$

$1.15 \pm 0.35^{\mathrm{b}}$

$4.60 \pm 0.99^{\mathrm{a}}$

$0.05 \pm 0.07^{\mathrm{c}}$

$0.75 \pm 0.07^{\mathrm{ab}}$

$0.00 \pm 0.0^{\mathrm{a}}$

$0.00 \pm 0.0^{\mathrm{d}}$

$58.35 \pm 0.07^{\mathrm{a}}$

$66.1 \pm 2.54^{\mathrm{a}}$

\subsection{5}

63.75

0.03

Means with the different letters in the same row are significantly different $(P<0.05)$.

$\mathrm{SFAs}=$ Saturated fatty acids; MUFAs $=$ Monounsaturated fatty acids; PUFAs $=$ Polyunsaturated fatty acids .

\section{$53.78 \pm 0.63^{\mathrm{a}}$}

$0.26 \pm 0.1^{\mathrm{a}}$

$0.43 \pm 0.0^{\mathrm{a}}$

$0.76 \pm 0.0^{\mathrm{b}}$

$1.92 \pm 0.0^{\mathrm{a}}$

$0.66 \pm 0.8 b^{c}$

$1.02 \pm 0.0^{\mathrm{a}}$

$0.49 \pm 0.0^{\mathrm{b}}$

$0.43 \pm 0.0^{\mathrm{a}}$

$2.06 \pm 0.0^{\mathrm{c}}$

$2.37 \pm 0.0^{\mathrm{c}}$

$10.34 \pm 0.75^{\mathrm{d}}$

3.37

7.02

0.48
$30.14 \pm 0.53^{\mathrm{c}}$

$0.65 \pm 0.90^{\mathrm{a}} \quad 0.55 \pm 0.01^{\mathrm{a}}$

$0.39 \pm 0.01^{\mathrm{a}} \quad 0.81 \pm 0.0^{\mathrm{a}}$

$0.54 \pm 0.08^{\mathrm{b}} \quad 0.00 \pm 0.0^{\mathrm{b}}$

$1.04 \pm 0.12^{\mathrm{b}} \quad 1.16 \pm 0.02^{\mathrm{b}}$

$1.34 \pm 0.48^{\mathrm{b}} \quad 0.00 \pm 0.0^{\mathrm{c}}$

$0.49 \pm 0.22^{\mathrm{b}} \quad 0.00 \pm 0.0^{\mathrm{c}}$

$1.14 \pm 0.05^{\mathrm{a}} \quad 1.14 \pm 0.03^{\mathrm{a}}$

$0.39 \pm 0.01^{\mathrm{a}} \quad 0.81 \pm 0.0^{\mathrm{a}}$

$6.23 \pm 0.79^{\mathrm{b}} \quad 10.83 \pm 0.0^{\mathrm{a}}$

$0.00 \pm 0.0^{\mathrm{d}}$

$12.1 \pm 2.60^{\mathrm{d}}$

$45.5 \pm 0.0^{\mathrm{b}}$

$60.01 \pm 0.02^{\mathrm{b}}$

58.28
2.55

0.04

$\begin{array}{ll}2.63 & 2.55 \\ 9.62 & 58.28 \\ 0.28 & 0.04\end{array}$

sandard deviation 


\section{Saturated fatty acids (SFAs)}

There were no significant differences $(P>0.05)$ in the percentage concentrations of caproic acid (C6:0), capric acid (C10:0), pentadecanoic acid (C15:0), heneicosanoic acid (C21:0), and behenic acid (C22:0) among the different size classes and the eggs. Significant differences $(P<$ $0.05)$ however, were observed in the percentage concentrations of butyric acid (C4:0), caprylic acid (C8:0), undecanoic acid (C11:0), lauric acid (C12:0), tridecanoic acid (C13:0), myristic acid (C14:0), palmatic acid (C16:0), heptadecanoic acid (C17:0), stearic acid (C18:0), arachidic acid (C20:0) tricosanoic acid (C23:0) and lignoceric acid (C24:0). Other predominant SFAs for fish of different size classes were Tridecanoic acid (C13:0), Palmatic acid (C16:0), and Heptadecanoic acid (C17:0) especially in fish sizes of 21 to $30 \mathrm{~cm}$, and 31 to $40 \mathrm{~cm}$. Further analysis indicated low percentage concentrations of SFAs in the eggs $(5.07 \%)$, but these increased with increasing body length (Table 1).

\section{Monounsaturated fatty acids (MUFAs)}

There were no significant differences in the percentage concentration of eicosenoic acid (C20:1 w9) across the different fish size classes $(P>0.05)$. However, significant differences were observed in the percentage concentrations of myristoleic acid (C14:1 $\omega 5)$, cis-10-pentadecenoic acid (C15:1 $\omega 5)$, palmitoleic acid (C16:1 $\omega 7$ ), cis-10-heptadecenoic acid (C15:1 $\omega 5$ ), oleic acid (C18:1 $\omega 9)$, erucic (C22:1 $\omega 9)$ and nervonic acid (C24:1 $\omega 9)(P<0.05)$. Oleic acid was the dominant MUFAs in the fish size class of 21 to $30 \mathrm{~cm}$ at $6.92 \%$ while cis-10-heptadecenoic acid was dominant in the egg samples and in the fish size class of 1 to $10 \mathrm{~cm}, 11$ to $20 \mathrm{~cm}$, and 21 to $30 \mathrm{~cm}$ (Table 1). Erucic acid was dominant in the fish size classes of 21 to $30 \mathrm{~cm}$ and 31 to $40 \mathrm{~cm}$. The highest levels of MUFAs were observed in the size classes of 21 to $30 \mathrm{~cm}(65.9 \%)$ and 31 to $40 \mathrm{~cm}(47.37 \%)$.

\section{Polyunsaturated fatty acids (PUFAs)}

The proportion of PUFAs found in the fish size categories ranged from $57.15 \pm 4.87 \%$ in 1 to $10 \mathrm{~cm}, 66.1 \pm 2.54 \%$ in 11 to $20 \mathrm{~cm}, 10.34 \pm 0.75 \%$ in 21 to $30 \mathrm{~cm}, 12.1 \pm 2.60 \%$ in 31 to $40 \mathrm{~cm}$, and $60.01 \pm 0.02 \%$ in eggs. There were no significant differences in the percentage concentration of $\alpha$-linolenic acid (C 18:3 $\omega 3$ ), eicosatrienoic acid (C 20:3 $\omega 3$ ), and dihomo- $\gamma$ - linolenic acid (C $20: 3 \omega 6)(P>0.05)$ among the size classes and the eggs. However, significant differences were observed in the percentage concentrations of eicosapentaenoic acid (C 20:5 $\omega 3$ ) docosahexaenic acid (C 22:2 $\omega 6$ ), linoleic acid (C 18:2 $\omega 6), \gamma$-linolenic acid (C 18:3 $\omega 6$ ), eicosadienoic acid (C 20:2 $\omega 6)$, arachidonic acid (C 20:4 $\omega 6$ ), and docosadienoic acid (C 22:2 $\omega 6$ ).

\section{Discussion}

Age variation and sex maturity in the same species contribute to the significant differences in the total lipid contents (Namulawa et al., 2011). In addition, age impacts significantly on the variation of fatty acid dietary requirements in fish. Fatty acids have been reported to play a major role in broodstock nutrition and greatly influence the quality of developing eggs and larvae (Izquierdo et al., 2001). 
In this study, high levels of ARA and docosadienoic acid were observed in the eggs of $A$. baremoze. The importance of ARA in fish nutrition has tended to be ignored in preference to EPA and DHA (Bell and Sargent, 2003). However, studies indicate that ARA provides precursors for the synthesis of eicosanoids which are responsible for immune regulatory activities (Bell and Sargent, 2003). ARA values tend to increase when fish are exposed to unusual environments (Bell and Sargent, 2003; Yanes-Roca et al., 2009). Elevated ARA observed during dietary supplementation can improve growth, survival, and resistance to stress (Bell and Sargent, 2003). It is likely that, at specific stages in the life cycle of fish, high levels of ARA and docosadienoic acid may be required to cope with periods of environmental stress.

Probably, the high ARA and docosadienoic acid values observed in this study may be due to the temporal alteration of habitat that wild $A$. baremoze adults are exposed to during the spawning seasons. Pre-reproductive $A$. baremoze adults undertake upriver migration from reservoirs during the year (Diouf et al., 2020). This may be one of the reasons why ARA values were high in $A$. baremoze eggs. However, in order to get more conclusive, and reliable, results, more work should be done regarding the diet, and feeding habits of $A$. baremoze in the wild. The effects of docosadienoic acid on the reproductive performances, as well as the involved mechanisms, warrant further studies.

Regarding the SFA values, there were high concentrations of $\mathrm{C} 17: 0$ and $\mathrm{C} 18: 0$ within the size class of 31 to $40 \mathrm{~cm}$ implying a particular necessity for these acids in the growth of $A$. baremoze. Generally, the total SFAs also increased with increasing fish size. The presence and content of these fatty acids have been usually associated to planktonic or bacterial sources. Among the MUFAs, erucic acid and cis-10-heptadecenoic acid were among the dominant fatty acids across the fish samples. Their presence in the samples of $A$. baremoze indicates that these fatty acids are naturally present in the aquatic food chain. It could also be assumed that $A$. baremoze is capable of producing erucic acid from shorter chain fatty acids, such as oleic acid as well as from longer chain fatty acids, such as nervonic acid. Sissener et al. (2018) reported that erucic acid was highly variable, among both species and individual samples within the same species and the highest concentrations was found in fish liver, fish oil, and in the fillet of oily fish. Additionally, the high levels of MUFAs observed in the category range of 21 to $30 \mathrm{~cm}$ and 31 to $40 \mathrm{~cm}$ could be related to physiological factors and seasonal temperature cycles.

In this study, fish size in the range of 11 to $20 \mathrm{~cm}$ had relatively higher levels of PUFAs than fish in the categories of 1 to $10 \mathrm{~cm}, 21$ to $30 \mathrm{~cm}$, and 31 to $40 \mathrm{~cm}$ size classes. PUFAs play an important role in the gonadal maturation (Rainuzzo et al., 1997; Izquierdo et al., 2001; Sargent et al., 2002). Thus, the relatively high levels of PUFAs observed in the range of 11 to $20 \mathrm{~cm}$ might be related to the reproductive stage and size at maturity for this fish. A study by NaFIRRI (2012) indicated that $A$. baremoze is estimated to mature at $17 \mathrm{~cm}$ fork length compared to the historical size of $27 \mathrm{~cm}$.

Among the $\omega 3$ PUFAs, EPA was significantly highest (51.85 $\pm 1.06 \%)$ in the 1 to $10 \mathrm{~cm}$ fish size class compared to $0.45 \pm 0.50 \%$ in the 11 to $20 \mathrm{~cm}$ size class, $0.76 \pm 0.0 \%$ in the 21 to $30 \mathrm{~cm}$, and $0.54 \pm 0.08 \%$ in the 31 to $40 \mathrm{~cm}$ size class. The dominance of EPA might be attributed to the feeding habit of fish in this size class. Microalgae and zooplankton are important sources of EPA (Robert et al., 2014; Schneedorferova et al., 2015). Fish in this size category is likely to feed lower in the food chain because of the developing digestive structure. In addition, freshwater fish can also synthesize EPA through enzymatic pathways characterized by sequential desaturation and elongation actions (Glencross, 2009). It is thus likely that fish in this size category utilizes zooplankton as its main food item. Tocher (2003) reported that EPA move through the food chain unchanged via zooplankton to fish. A. baremoze has a flexible diet, shifting from zooplankton to zoobenthos, detritus, and macrophytes as plankton densities decline (Kasozi et al., 2017). Findings reported by Campbell et al. (2005) on food web structure 
in Lake Albert suggest that ontogenetic shifts occurred in the diet of A. baremoze partly driven by structural changes in the feeding apparatus and morphology that unlock new and unexploited feeding opportunities from phytoplankton and small zooplankton during their premetamorphosis stages to larger zooplankton. Further observations indicate that the percentage concentration of $\alpha$-linolenic acid was not significant among the different size classes. Lipids from phytoplankton are generally poor in linoleic acid. This might explain the low levels of $\alpha$-linolenic acid observed in this study since phytoplankton form part of $A$. baremoze diet.

\section{Conclusion}

This study provided the first description of the fatty acid profiles of $A$. baremoze, an economically important fish species in Uganda. The study indicates that there are considerable variations in the fatty acid profiles according to fish size classes and since no work has been published before to describe fatty acids composition of $A$. baremoze, this study provides a better understanding of its biochemical fatty acid needs. This will consequently guide to develop artificial feeding strategies for $A$. baremoze during culture. However further research may be needed to estimate the seasonal changes in the fatty acid composition of this fish.

\section{Disclosure statement}

No potential conflict of interest was reported by authors.

\section{Funding}

This work was supported by the National Agricultural Research Organization Competitive Grant Scheme (CGS Project ID/no: CGS/4/32/14), under the World Bank funded Agricultural Technology and Agribusiness Advisory Services (ATAAS) project.

\section{References}

Baker, R., Buckland, A. and Sheaves, M., 2014. Fish gut content analysis: robust measures of diet composition. Fish and Fisheries, 15:170-177.

Bell, J.G. and Sargent, J.R., 2003. Arachidonic acid in aquaculture feeds: current status and future opportunities. Aquaculture, 218: 491-499.

Bligh, E.G. and Dyer, W.J., 1959. A rapid method of total lipid extraction and purification. Canadian Journal of Biochemistry and Physiology, 37: 911-917.

Britton, J.R. and Busst, G.M.A., 2018. Stable isotope discrimination factors of omnivorous fishes: influence of tissue type, temperature, diet composition and formulated feeds. Hydrobiologia, 808: 219-234.

Campbell, L.M., Wandera, S.B., Thacker, R.J., Dixon, D.G. and Hecky, R.E., 2005. Trophic niche segregation in the nilotic ichthyofauna of Lake Albert (Uganda, Africa). Environmental Biology of Fishes, 74: 247-60.

Diouf, K., Akinyi, E., Awaïss, A., Azeroual, A., Getahun, A., Lalèyè, P. and Twongo, T.K., 2020. Alestes baremoze. The IUCN red list of threatened Species 2020.https://dx.doi.org/10.2305/IUCN.UK.2020-2.RLTS.T182568A134737567.en Accessed on $20^{\text {th }}$ August 2020.

Glencross, B.D., 2009. Exploring the nutritional demand for essential fatty acids by aquaculture species. Reviews in Aquaculture, 1: 71-124. 
Gümüş, A., Yilmaz, M. and Polat, N., 2002. Relative importance of food items in feeding of Chondrostoma regium Heckel, 1843, and its relation with the time of annulus formation. Turkish Journal of Zoology, 26: 271-278.

Hamre, K., Yúfera, M., Rønnestad, I., Boglione, C., Conceiçao, L.E.C. and Izquierdo, M., 2013. Fish larval nutrition and feed formulation: knowledge gaps and bottlenecks for advances in larval rearing. Reviews in Aquaculture, 5: S26-S58.

Izquierdo, M.S., Fernandez-Palacios, H. and Tacon, A.G.J., 2001. Effect of broodstock nutrition on reproductive performance of fish. Aquaculture, 197: 25-42.

Kasozi, N., Degu, G., Mukalazi, J., Kato, C.D., Kisekka, M., Owori -Wadunde, A., Kityo, G. and Namulawa, V.T., 2017. Histomorphological description of the digestive system of pebbly fish, Alestes baremoze (Joannis, 1835). The Scientific World Journal, 8591249: 1-9.

Kasozi, N., Iwe, G., Sadik, K., Asizua, D. and Namulawa, V.T., 2019. Dietary amino acid requirements of pebbly fish, Alestes baremoze (Joannis, 1835) based on whole body amino acid composition. Aquaculture Reports, 14:1-6.

Kinsella, J.E., Shimp, J.L., Mai, J. and Weihrauch, J., 1977. Fatty acid content and composition of freshwater finfish. Journal of the American Oil Chemists' Society, 54: 424-429.

Morrison, W.R. and Smith, L.M., 1964. Preparation of fatty acid methyl esters and dimethylacetals from lipids with boron fluoride-methanol. Journal of Lipid Research, 5: 600608.

Namulawa, V.T., Mbabazi, J. and Kwetegyeka, J., 2011. Fatty acid profiles of the eggs and juvenile muscle of Nile perch (Lates niloticus, L.1758) caught from Lake Victoria, Uganda. African Journal of Pure and Applied Chemistry, 5: 127-135.

National Fisheries resources Research Institute (NaFIRRI). 2012. Capture fisheries in Uganda; Policy Brief No. 1 of 2012; The Nile perch fishery; traditional and emerging fisheries; overfishing and the use of illegal gears on Lake Albert. Jinja, Uganda.

NRC (National Research Council), 1993. Nutrient requirements of fish. National Academy Press, Washington, DC, USA, 114-124.

Post, D.M., 2002. Using stable isotopes to estimate trophic position: models, methods, and assumptions. Ecology, 83: 703-718.

Rainuzzo, J.R., Reitan, K.I. and Olsen, Y., 1997. The significance of lipids at early stages of marine fish: a review. Aquaculture, 155: 103-115.

Robert, A., Mfilinge, P., Limbu, S.M. and Mwita, C.J., 2014. Fatty acid composition and levels of selected polyunsaturated fatty acids in four commercial important freshwater fish species from Lake Victoria, Tanzania. Journal of Lipids, 2014: Article ID 712134.

Robin, J.H., Regost, C., Arzel, J. and Kaushik, S.J., 2003. Fatty acid profile of fish following a change in dietary fatty acid source: model of fatty acid composition with a dilution hypothesis. Aquaculture, 225: $283-293$.

Sargent, J.R., Tocher, D.R. and Bell, J.G., 2002. The lipids, In: J.E Halver and R.W.Hardy (Editors), Fish Nutrition, 3rd edition. Academic Press, San Diego, pp. 181-257.

SAS Institute Inc. 2004. SAS/STAT ${ }^{\circledR} 9.1$ User's Guide. Cary, NC: SAS Institute Inc. USA.

Schneedorferova, I., Tomčala, A. and Valterova, I., 2015. Effect of heat treatment on the n3/n-6 ratio and content of polyunsaturated fatty acids in fish tissues. Food Chemistry, 176: 205-211.

Shearer, K.D., 2000. Experimental design, statistical analysis and modeling of dietary nutrient requirement studies for fish: a critical review. Aquaculture Nutrition, 6: 91-10.

Sissener, N.H., Ørnsrud, R., Sanden, M., Frøyland, L., Remø, S. and Lundebye, A.-K., 2018. Erucic Acid (22:1n-9) in fish feed, farmed, and wild fish and seafood products. Nutrients, 10 : $1-12$. 
Tocher, D.R., 2003. Metabolism and functions of lipids and fatty acids in teleost fish. Revies in Fisheries Science, 11:107-184.

Yanes-Roca, C., Rhody, N., Nystrom, M. and Main, K.L., 2009. Effects of fatty acid composition and spawning season patterns on egg quality and larval survival in common snook (Centropomus undecimalis). Aquaculture, 287: 335-340. 